\title{
Changes in the stability of ultra-pasteurized lactose-free milk upon storage
}

\author{
Nancy Michael Rosas González¹, María Cristina Cueto-Wong'1, Rosa Idalia Armenta-Corral', \\ Silvia Guadalupe Fernández-Michel'1, Jolanta Elzbieta Marszalek¹, Gabriela Ramos-Clamont Montfort* \\ ${ }^{1}$ Laboratorio de Ciencia y Tecnología de los Alimentos Orientados a la Salud, Facultad de Ciencias Biológicas Universidad Autónoma de \\ Coahuila, ${ }^{2}$ Coordinación de Ciencia de los Alimentos, Centro de Investigación en Alimentación y Desarrollo A.C
}

\section{A B S TR A C T}

\begin{abstract}
Lactose-free dairy products are a valued consumer option for lactose intolerant individuals. Short-term ultra-high pasteurization (UHT) allows the preparation of sterile milk products. Manufactures define the useful shelf life of UHT milk as 120 days. This study analyses lactose-free milk with low-fat content over 120 days of shelf storage. Milk composition, microbial presence, structure (micellar size and zeta potential), color, $\mathrm{pH}$, and protein hydrolysis were examined. At 120 days of storage the $\mathrm{pH}$ decrease, change in particle size distribution, and significant browning of the milk were detected indicating meaningful changes in the milk structure. The changes occurring in the lactose-free milk are related to the introduction of a large number of reducing sugars as a result of delactosylation of the milk. Studied milk had no microbial contamination nor showed the presence of by-products contamination such as proteases (minimal hydrolysis after long time storage).
\end{abstract}

Keywords: Lactose-free milk; Low-fat; Stability; Ultra-pasteurized milk shelf life

\section{INTRODUCTION}

Ultra-high temperature pasteurization (UHT) is a technological process that sterilizes food liquids like milk, by heating them at $132^{\circ} \mathrm{C}-138^{\circ} \mathrm{C}$ for $2 \mathrm{~s}$, followed by rapid cooling to $4{ }^{\circ} \mathrm{C}$. Once it has been cooled, the UHT milk is packaged into an airtight, light-blocking, and sterile containers, typically a Tetra Pak carton. This process allows UHT milk to be stored without any need for refrigeration for months. However, when the packaging is opened, bacteria from the outside can spoil the milk within a week or two, under refrigeration conditions (Deeth and Lewis, 2017). UHT milk has seen large success in Europe, the United States, Canada, and more recently in Mexico. From 2009 to 2016 the world market for UHT milk increased annually by $5.7 \%$, reaching a volume of around 94.9 trillion liters in 2016 and the global UHT milk market is expected to reach US $\$ 135$ billion by 2020 (USDA, 2018). In Mexico, UHT milk production in 2017 was 3.6 million thousand liters. UHT milk is consumed more in the south and central region of Mexico because it can be delivered and sold without the added cost of refrigeration. In addition, many more consumers in the northern part of Mexico are shifting to UHT milk due to continual innovation and promotion of the dairy processors. Mexican dairy industry estimates that UHT milk accounts for 80 percent of its sales, while fresh pasteurized milk accounts for 20 percent (USDA, 2018).

Based on their lipid content the UHT milk is classified into full fat (whole), low fat or fat-free milk, and semi-skimmed milk. Low fat and semi-skimmed types are most popular among adult consumers, who prefer healthy products and low-calorie intake (Briefel and Johnson, 2004). Another dairy alternative in the market is low fat and semi-skimmed lactose-free UHT milk. Lactose-free UHT milk provides essential nutrients present in regular milk, like protein, vitamins, and calcium, but does not contain lactose which is, for some consumers, a difficult to digest sugar (Dekker et al., 2019).

Lactose intolerance is a condition that is caused by insufficient levels or lack of lactase enzyme. Upon consumption of lactose, the lactase deficiency manifests itself with a variety of gastrointestinal symptoms such as

\footnotetext{
*Corresponding author:

Gabriela Ramos Clamont Montfort, Coordinación de Ciencia de los Alimentos, Centro de Investigación en Alimentación y Desarrollo A.C.

E-mail: gramos@ciad.mx

Received: 28 August 2020; $\quad$ Accepted: 11 May 2020
} 
diarrhea, flatulence, abdominal pain, nausea, and vomiting (Bayless et al., 2017). Lactose intolerance occurs mostly in populations that traditionally consume small quantities of milk such as Asian and African inhabitants. Also, elderly people can develop lactose intolerance. In fact, it has been reported that nearly $75 \%$ of the worldwide population is lactose intolerant (Silanikove et al., 2015). One of the solutions for people with lactose intolerance is the consumption of lactose-free products offered by the dairy industries. As a result, the lactose-free market is actually the most rapidly growing in the dairy industry (Dekker et al., 2019).

Ultra-pasteurized (UHT) lactose-free products, which are subjected to a short-term ultra-high sterilization temperature and aseptic packaging can be stored at room temperature for a period of 3-6 months, until opened (Richards et al., 2016). However, most manufacturers have established the useful shelf life of UHT milk to be 120 days after the ultra-pasteurization process (De Longhi et al., 2012). This is because some biochemical (enzymatic) and physicochemical changes can affect the sensory quality of long-term-stored UHT causing rejection of the consumer (Sunds et al., 2018). The main physicochemical changes that occur upon UHT milk storage are sedimentation, gelation (due to a destabilization of casein micelles and further interaction with some minerals), and milk browning due to the Maillard reactions which also can cause off-flavors (Deeth and Lewis, 2017).

Although the mechanism of the age gelation of UHT milk has been studied extensively there is no agreement on a single mechanism describing this process. (D'Incecco et al., 2018) The gelation of UHT milk occurs as a two-step process, where firstly polypeptides dissociate from casein micelles and then is followed by physicochemical reactions leading to the formation of a three-dimensional network. (Datta and Deeth, 2001)

This heat-induced aggregation is caused by dissociation of Kappa-casein $(\mathrm{K}-\mathrm{CN})$ from casein micelle and its interaction with calcium and $\beta$-lactoglobulin (Anema, 2019). Singh and Latham (1993) demonstrated the formation of complexes composed of $\beta$-lactoglobulin and $\kappa-\mathrm{CN}$ in UHT milk in the initial steps of the heat process. These complexes remained at stable levels at $\mathrm{pH}$ 6.67, however, an increase in $\mathrm{pH}$ produced an increase in the formation of these complexes. In addition, in lactose-free milk, there is a larger increase in $\mathrm{pH}$ upon storage than in milk with lactose (Al-Saadi et al., 2013). In contrast, high sedimentation was reported in UHT milk samples with a $\mathrm{pH}$ lower than 6.67 (Gaur et al., 2018). Sedimentation also increases in UHT milk with storage temperature (Gaur et al. 2018; Malmgren et al., 2017). Early studies in UHT milk showed that the level of fat in milk does not affect sedimentation (Hawran et al., 1985).

Protein hydrolysis and bitterness development in addition to oxidative and lipolytic changes in the milk lipid phase can occur if thermally resistant enzymes are present (Jansson et al., 2014; Lu et al., 2019). For example, when heat-stable peptidases are present in UHT milk, they show activity that deteriorates the UHT milk during storage leading to a set of defects occurred in the order: bitterness, particle formation, creaming, sediment formation, and finally gelation (Stoeckel et al., 2016)

A decrease in the milk natural $\mathrm{pH}$ can happen upon storage driving changes in physicochemical parameters of millk that affect the internal structure of the casein micelles, CM, as well as their external surface layers. (Sinaga et al. 2017). Acidified milk decreases the net charge of caseins and causes the solubilization of colloidal calcium phosphate from the micelles into the solution. (McMahon et al., 2009).

Acidification can also modify the conformation and interactions of whey proteins during the UHT milk storage as demonstrated by Al-Saadi and Deeth (2008) using reversed-phase HPLC or by Holland et a.l (2011) using 2D electrophoresis. Decrease of $\mathrm{pH}$ during stored is has been attributed to the formation of Maillard reactions intermediates, enzymatic proteolysis and formation of acetic and formic acids. These changes also affect UHT milk flavor (Gaucher et al., 2008)

Another parameter that can change during storage is the color of the milk which is a consequence of subjecting milk to heat treatments such as ultra-pasteurization. The non-enzymatic darkening is mediated by Maillard reactions. These reactions occur between the free $\varepsilon$-amino-groups of the milk proteins and the non-reducing carbohydrates present in the milk causing the formation of molecules that decrease the whiteness of the milk and that increase the yellow-brown coloration upon the storage (Jansson et al., 2014).

Lysine lactosylation is the first Maillard reaction that occurs during the ultra-pasteurization process and continues during the storage of UHT milk. Holland et al (2011) demonstrated a higher degree of lactosylation in $\beta$-lactoglobulin and $\alpha$-lactalbumin when the UHT milk was stored at $40{ }^{\circ} \mathrm{C}$ compared to that stored at $28{ }^{\circ} \mathrm{C}$. At the same time, advanced Maillard reactions can promote a cross-linking of proteins and peptides as well as a formation of lysinoalanine (LAL, which has been found to cause kidney damage). Faits et al (2000) tested the influence of the type of processing in milk on the formation of LAL. They found higher levels of these peptides in sterilized milk 
than in UHT milk. Maillard reactions in lactose-free milk proceed mainly via LAL formation. Al-Saadi et al. (2013) showed a much higher concentration of LAL and a much lower percentage of cross-linked proteins in lactose-free milk in comparison to milk containing lactose.

The objective of this study was to investigate the physicochemical changes occurring during storage of UHT lactose-free low fat or skimmed milk for 90 days (starting 30 days after production and ending 120 days after production), regarding physicochemical, microbiological, stability and electrophoretic analysis.

\section{MATERIALS AND METHODS}

\section{Lactose-free, UHT milk samples collection}

Three commercial brands of UHT Milk (A, B, and C) packed in Tetra Pack cartons were used for this study. Two of the brands are produced in Mexico and one in the United States. Two types of milk were sampled from each brand Lactose-Free Low Fat UHT milk ( $\left.{ }^{\mathrm{LF}} \mathrm{LF}-\mathrm{UHT}\right)$ and Lactose-Free Semi Skimmed UHT milk (LFSS-UHT). The cartons of milk were purchased in local stores in Torreón and Hermosillo, Mexico. Milk cartons were selected with matched dates of production and expiration. The samples were analyzed at 30,60, 90, and 120 days after manufacture (De Longhi et al., 2012). Each sample of brands was collected in triplicates.

\section{Physiochemical analysis}

The content of fat, carbohydrates, and protein was obtained using a Milkoscope Expert Automatic Milk Analyzer (Scope, Electric, Germany). The $\mathrm{pH}$ was determined in a pH meter HI2209, (Hanna Instruments, USA). Titratable acidity was analyzed according to AOAC Method (947.05) (Horwits, 2000). The results were expressed as a percentage of lactic acid. The stability of milk proteins was determined with the alcohol test (Horwits, 2000. All analyses were performed in triplicates.

\section{Microbiological analysis}

Microbiological analyses consisted of bacterial plate count of aerobic and anaerobic, mesophilic and thermophilic bacteria. All analyses Samples of milk ${ }^{\mathrm{LF}} \mathrm{LF}-\mathrm{UHT}$ or ${ }^{\mathrm{LF} S S}$ UHT were carried out in triplicate after each storage period (30, 60, 90, and 120 days). The results were expressed as colony forming units $(\mathrm{CFU} / \mathrm{mL})$, based on the procedure described in the FDA-Bacteriological Analysis Manual (FDA-BAM, 1998).

\section{Determination of color changes}

The color of UHT milk was determined with a colorimeter Chroma-Meter CR-30 (Konica Minolta, USA) equipped with a DP-301 data processor. The calibration of the device and the color determinations were made according to the manufacturer's instructions. The color values were expressed in CIELAB System, as lightness $\left(\mathrm{L}^{*}\right)$, redness $\left(a^{*}\right)$, and yellowness $(\mathrm{b})$.

Color determinations were made at 30, 60, 90, and 120 days of storage. The Whiteness Index (WI) was calculated with the following formula

$$
W_{I}=\left[\left(100-L^{*}\right)^{2}+\left(b^{*}\right)^{2}+\left(a^{*}\right)^{2}\right]^{(1 / 2)}
$$

The color change $\left(\Delta \mathrm{E}^{*}\right)$ was obtained using the following equation (Baldevbhai et al., 2012):

$$
\Delta \mathrm{E}^{*}=\left[\left(\mathrm{L}_{2}^{*}-\mathrm{L}_{1}^{*}\right)+\left(\mathrm{b}_{2}^{*}-\mathrm{b}_{1}^{*}\right)+\left(\mathrm{a}_{2}^{*}-\mathrm{a}_{1}^{*}\right)\right]^{(1 / 2)}
$$

All analyses were performed at $25^{\circ} \mathrm{C}$ with three independent observations.

\section{Size and net charge of particles}

The mean particle diameters and size distributions were measured by dynamic light scattering (DLS) using a NanoZS90 Zetasizer Analyzer (Malvern, UK), at a $90^{\circ}$ scattering angle and room temperature of $25^{\circ} \mathrm{C}$. The determinations were made in triplicates according to Gaucher et al. (20008). All the determinations were made in triplicates using the software Zetasizer version 7.01 (Malvern, UK).

\section{Reaction with ortho-phthalaldehyde}

The hydrolysis of the $\alpha$-amino groups of milk proteins was determined by the formation of complexes with ortho-phthalaldehyde (OPA) in the presence of $\beta$-mercaptoethanol, according to the method proposed by Silvestre et al. (2012). The analysis was performed at 30, 60,90 , and 120 days. All the determinations were made in triplicates. The percentage of hydrolysis $(\% \mathrm{DH})$ of milk proteins was calculated according to Silvestre et al. (2012), using the following formula:

$$
\% \mathrm{DH}=(\mathrm{ABS} \cdot 1.934 \cdot \mathrm{d}) / \mathrm{c}
$$

Where ABS is the absorbance of the samples, $d$ is the dilution factor, and $\mathrm{c}$ the protein concentration of the sample $\left(\mathrm{mg} \mathrm{L}^{-1}\right)$. The concentration of protein was estimated by the Bradford Method (1976). As a control, the milk samples ( ${ }^{\mathrm{LF}} \mathrm{LF}-\mathrm{UHT}$ and ${ }^{\mathrm{LF} S S}$-UHT) were treated with pancreatin (enzyme to the substrate at 80:100 w/w), for $5 \mathrm{~h}$ according to Silvestre et al. (2012).

\section{SDS-PAGE electrophoresis}

Electrophoretic characterization of milk samples ${ }^{\mathrm{LF}} \mathrm{LF}$ UHT and ${ }^{\mathrm{LF}} \mathrm{S}$-UHT at the beginning (30 days) and end (120 days) of the product shelf-life was carried out by sodium dodecyl sulfate-polyacrylamide gel electrophoresis 
(SDS-PAGE) electrophoresis. 12\% polyacrylamide gels were prepared under denaturing and reducing conditions according to Laemmli (1970). The concentration of protein in milk samples was estimated according to Bradford (1976), using a standard curve of bovine serum albumin (BSA). $15 \mu \mathrm{g}$ of protein were applied in each well. The gels were run in a Mini-PROTEAN II Cell, (BioRad, Hercules, CA, USA) at 100 volts and then dyed with Coomassie blue. The molecular mass of the protein was determined with Gel Doc ${ }^{\mathrm{TM}} \mathrm{XR}+$ Gel Documentation System using the software Image Lab (Bio-Rad, Hercules, CA, USA) and molecular mass standards with a broad molar mass range (Bio-Rad, Hercules, CA, EUA).

\section{Photographic documentation}

Photographs of the experiments performed are shown in Fig. 1

\section{Statistical analysis}

All the experiments were run in triplicates applying a completely random design. The results were submitted to an analysis of ANOVA variance, with a significance level $\alpha=0.05$. The mean difference was obtained with the Tukey Kramer test. The Statgraphics Centurion XVI program was used; 2009 version.

\section{RESULTS AND DISCUSSION}

\section{Changes in physicochemical and microbiological parameters during shelf life}

Table I shows the content of lipids, carbohydrate (other than lactose), and milk proteins for ${ }^{\mathrm{LF}} \mathrm{LF}-\mathrm{UHT}$ and ${ }^{\mathrm{LF} S S}$ -
UHT. The lipid content within the same brand did not vary ( $p>0.05)$ during the shelf life (120 days). The ${ }^{\mathrm{LF}} \mathrm{LF}-$ UHT milk from brand A and C showed lipid percentages between 0.4 and $0.6 \%$, while the milk $\mathrm{B}$ was between 1.4 and $1.5 \%$. These values correspond to those declared on the nutritional label. However, they are above the Mexican standard established for low-fat milk which indicates that the fat content of these types of milk should not exceed 0.5\% (NOM-155-SCFI-2012). Based on fat content, brand B milk matches the "reduced-fat" category instead of the "low-fat" one according to the FDA milk classification (FDA, 1998). The lipid content in ${ }^{\mathrm{LF}}$ SS-UHT milk was similar among the different brands and did not vary ( $p>0.05)$ during the 120 days of storage having values from 2.0 and $2.5 \%$. These fat levels place the ${ }^{\mathrm{LF} S S-U H T}$ milk into the reduced fat milk class according to the FDA.

The contents of carbohydrates and protein in both types of milk were the same $(p>0.05)$ during the first 90 days of storage, corresponding to those stated on the nutritional label of each one of the milk's brands. However, on day 120 of storage, a decrease $(p<0.05)$ was detected both in the percentage of carbohydrates and the percentage of protein. In addition, the alcohol test was negative during the first 90 days of storage. However, the alcohol test was positive at 120 days of storage for all brands and types of milk (Table 1). The alcohol test is a rapid and economical test that is used by the Latin American dairy industry, to measure the stability of raw milk to heat treatment. If cow's milk precipitates when mixed with an equal volume of $72-75 \%$ ethanol solution, it is not suitable for the production of UHT milk (Molina et al., 2001). The ethanol induces
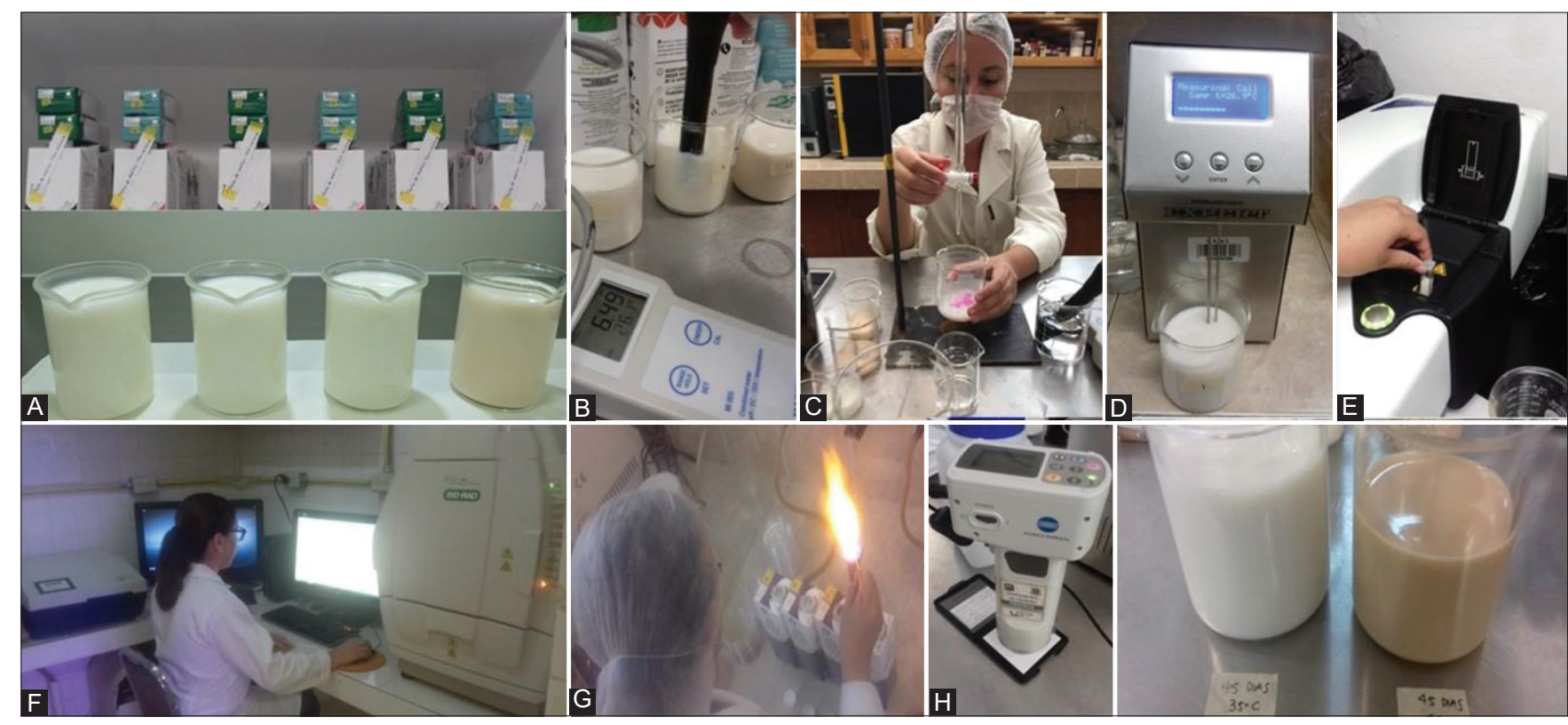

Fig 1. Photo collage of some of the experiments carried out in this study. A) Samples analyzed; B) pH measurement; C) Titratable acidity; D) Composition analysis; E) Size and surface charge; F) Gel documentation system; G) Microbiological analysis; H) Color determination. 
González, et al.

Table 1: Composition and protein precipitation of LFLF-UHT y LFSS-UHT milk

\begin{tabular}{|c|c|c|c|c|c|}
\hline \multicolumn{6}{|c|}{ LFLF-UHT Milk } \\
\hline Analysis & Brand & $30^{*}$ & $60^{*}$ & $90^{*}$ & $120^{*}$ \\
\hline \multirow[t]{3}{*}{ Lipids (\%) } & $A$ & $0.4 \pm 0.10^{a}$ & $0.5 \pm 0.02^{\mathrm{a}}$ & $0.5 \pm 0.02^{a}$ & $0.4 \pm 0.09^{a}$ \\
\hline & B & $1.4 \pm 0.05^{a}$ & $1.4 \pm 0.10^{a}$ & $1.5 \pm 0.08^{\mathrm{a}}$ & $1.4 \pm 0.08^{2}$ \\
\hline & C & $0.6 \pm 0.12^{a}$ & $0.6 \pm 0.01^{a}$ & $0.6 \pm 0.02^{\mathrm{a}}$ & $0.6 \pm 0.10^{a}$ \\
\hline \multirow[t]{3}{*}{ Carbohydrates (\%) } & $A$ & $5.7 \pm 0.01^{a}$ & $5.6 \pm 0.01^{a}$ & $5.6 \pm 0.03^{a}$ & $5.4 \pm 0.02^{b}$ \\
\hline & $\mathrm{B}$ & $5.3 \pm 0.01^{\mathrm{a}}$ & $5.3 \pm 0.01^{a}$ & $5.4 \pm 0.02^{\mathrm{a}}$ & $5.0 \pm 0.01^{\mathrm{b}}$ \\
\hline & $\mathrm{C}$ & $5.5 \pm 0.01^{\mathrm{a}}$ & $5.5 \pm 0.02^{a}$ & $5.5 \pm 0.01^{a}$ & $5.1 \pm 0.03^{b}$ \\
\hline \multirow[t]{3}{*}{ Protein (\%) } & $A$ & $3.7 \pm 0.01^{\mathrm{a}}$ & $3.8 \pm 0.22^{\mathrm{a}}$ & $3.7 \pm 0.05^{\mathrm{a}}$ & $3.5 \pm 0.01^{b}$ \\
\hline & B & $3.6 \pm 0.00^{a}$ & $3.6 \pm 0.01^{a}$ & $3.6 \pm 0.02^{a}$ & $3.3 \pm 0.00^{b}$ \\
\hline & C & $3.7 \pm 0.04^{a}$ & $3.7 \pm 0.01^{a}$ & $3.7 \pm 0.01^{\mathrm{a}}$ & $3.4 \pm 0.02^{b}$ \\
\hline \multirow{3}{*}{ Protein precipitation (Alcohol test) } & A & - & - & - & + \\
\hline & B & - & - & - & + \\
\hline & C & - & - & - & + \\
\hline \multicolumn{6}{|c|}{ LFSS-UHT Milk } \\
\hline \multirow[t]{3}{*}{ Lipids (\%) } & A & $2.2 \pm 0.08^{a}$ & $2.2 \pm 0.01^{a}$ & $2.1 \pm 0.12^{a}$ & $2.2 \pm 0.02^{a}$ \\
\hline & B & $2.4 \pm 0.02^{\mathrm{a}}$ & $2.4 \pm 0.11^{a}$ & $2.4 \pm 0.09^{a}$ & $2.4 \pm 0.04^{2}$ \\
\hline & C & $2.2 \pm 0.05^{\mathrm{a}}$ & $2.2 \pm 0.07^{a}$ & $2.2 \pm 0.11^{a}$ & $2.3 \pm 0.19^{a}$ \\
\hline \multirow[t]{3}{*}{ Carbohydrates (\%) } & $A$ & $5.2 \pm 0.02^{\mathrm{a}}$ & $5.2 \pm 0.01^{a}$ & $5.2 \pm 0.01^{a}$ & $5.0 \pm 0.00^{b}$ \\
\hline & B & $5.2 \pm 0.01^{\mathrm{a}}$ & $5.2 \pm 0.01^{a}$ & $5.2 \pm 0.01^{\mathrm{a}}$ & $4.8 \pm 0.00^{\mathrm{b}}$ \\
\hline & $\mathrm{C}$ & $5.2 \pm 0.01^{\mathrm{a}}$ & $5.2 \pm 0.01^{\mathrm{a}}$ & $5.2 \pm 0.01^{\mathrm{a}}$ & $4.9 \pm 0.00^{b}$ \\
\hline \multirow[t]{3}{*}{ Protein (\%) } & A & $3.5 \pm 0.01^{a}$ & $3.5 \pm 0.00^{\mathrm{a}}$ & $3.5 \pm 0.00^{\mathrm{a}}$ & $3.2 \pm 0.01^{b}$ \\
\hline & B & $3.5 \pm 0.00^{\mathrm{a}}$ & $3.5 \pm 0.01^{a}$ & $3.5 \pm 0.00^{\mathrm{a}}$ & $3.2 \pm 0.01^{\mathrm{b}}$ \\
\hline & $\mathrm{C}$ & $3.5 \pm 0.00^{\mathrm{a}}$ & $3.5 \pm 0.01^{\mathrm{a}}$ & $3.5 \pm 0.00^{a}$ & $3.3 \pm 0.00^{\mathrm{b}}$ \\
\hline \multirow[t]{3}{*}{ Protein precipitation (Alcohol test) } & A & - & - & - & + \\
\hline & $\mathrm{B}$ & - & - & - & + \\
\hline & C & - & - & - & + \\
\hline
\end{tabular}

Values are means \pm error deviations. of three independent experiments. The different letters indicate statistically significant differences in the same brand $(p<0.05)$

destabilization of the casein micelles through a mechanism that has not been completely understood but is related to changes in the electrostatic interactions that coalesce the casein micelles (Ye and Harte, 2013). Because several factors affect the structure and interaction of caseins, such as the $\mathrm{pH}$ of milk and its mineral content (time of year and the lactation stage), the alcohol test has been labeled as subjective and non-specific (Anema, 2019). However, at the collection stations where other techniques are not available, it quickly defines the capacity of milk to be subjected to heat treatments such as ultra-pasteurization (Horne, 2016).

There is no scientific evidence that the alcohol test is a good indicator as to whether the ultra-pasteurized milk will form sediments during its storage and shelf life (Anema, 2019). However, in this study immediate appearance of precipitate was observed when ethanol at $75 \%$ was added to samples of LFLF-UHT and LFSS-UHT stored for 120 days. This behavior was not observed in the milk samples stored for 30, 60, and 90 days (Table 1). Thus, the alcohol test was used to quickly indicate a change in micelles structure that was later investigated in detail. At 120 days of storage, the $\mathrm{pH}$ decreased and an increase of titratable acidity was detected in all the samples (Fig. 2A and 2B). The levels of sedimentation of milk increased as $\mathrm{pH}$ decreased and vice versa due to the destabilization of $\mathrm{K}$-casein layer (Lewis et al., 2011). This type of casein is mainly responsible for the formation and sustaining of micelles by developing a steric repulsion layer around the other fractional caseins that are otherwise sensitive to precipitation in the presence of calcium (Horne, 2014). A decrease in $\mathrm{pH}$ can result in the reduction of steric repulsion produced by the $\mathrm{K}$ - casein. This, in turn, causes the rest of the casein to be open to interactions with the calcium present in milk and leads to the formation of a precipitate (Sinaga et al., 2017).

Fig. $1 \mathrm{~B}$ shows the changes in titratable acidity of the ${ }^{\mathrm{LF}} \mathrm{LF}-$ UHT and LFSS-UHT milk samples during storage. The titratable acidity ranges found in this study were between $1.9 \pm 0.01 \mathrm{gL}^{-1}$ and $2.4 \pm 0.05 \mathrm{gL}^{-1}$ which exceeds the values established by Mexican regulations (1.3 to $\left.1.7 \mathrm{~g} \mathrm{~L}^{-1}\right)$. The acidity levels in stored UHT milk drive changes in physicochemical parameters of milk (Sinaga et al. 2017). The values of total acidity of UHT milk in newly manufactured products were $1.5 \pm 0.01 \mathrm{~g} \mathrm{~L}^{-1}$, rising to 1.9 $\pm 0.01 \mathrm{~g} \mathrm{~L}^{-1}$ after 30 days of storage. At 60 days of storage, titratable acidity was at $2.2 \pm 0.01 \mathrm{gL}^{-1}$ which is similar to the study by De Longhi et al. (2012). Fig. 2B shows that the greatest changes in acidity $(\mathrm{p}<0.05)$ manifested after day 120 of storage $\left(2.4 \pm 0.05 \mathrm{~g} \mathrm{~L}^{-1}\right)$, being consistent 


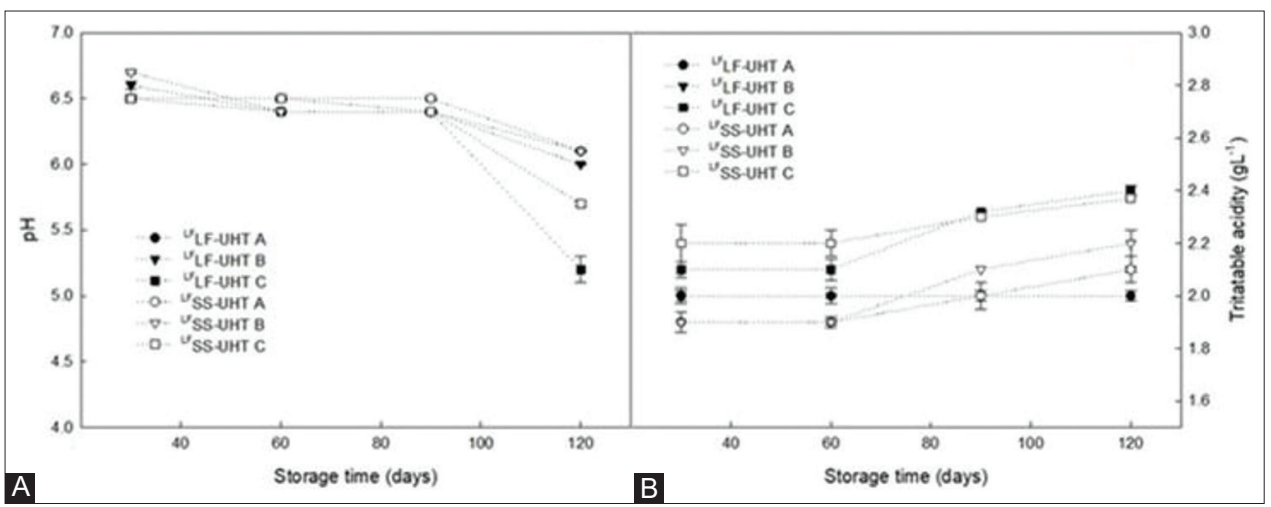

Fig 2. Evolution of $\mathrm{pH}(\mathrm{A})$ and titratable acidity (B) of samples of LFLF-UH and LFSS-UHT milk samples stored for 120 days. The data are the means of triplicate experiments, and the error bars indicate error deviations.

with the decrease in the $\mathrm{pH}$ of milk (Fig. 2A). It is well established that the acidity of the UHT milk increases and its $\mathrm{pH}$ decreases during storage (Gaucher et al., 2008). The change in acidity is attributed to Maillard reactions and more specifically to the formation of intermediaries such as acid anhydrides and formic acid over time (Malmgren et al., 2017).

\section{Microbiological analysis}

The presence of mesophilic and thermophilic bacteria, both aerobic and anaerobic were sought in the ${ }^{\mathrm{LF}} \mathrm{LF}-\mathrm{UHT}$ and LFSS-UHT milk samples. No microbial growth was detected in any of the brands and types of milk during the 120 days of storage. In contrast, De Longhi et al. (2012) found aerobic mesophilic bacteria $\left(6.7 \times 10^{3} \mathrm{CFU} / \mathrm{mL}\right)$ in some Brazilian brands of UHT whole milk, after 7 days of storage at $35{ }^{\circ} \mathrm{C}$. Also, Pinto et al. (2018) found a bacterial presence higher than $1.0 \times 10^{2} \mathrm{CFU} / \mathrm{mL}$ in $45 \%$ of UHT milk brands. Ultra-pasteurization is a process that aims to produce commercially sterile milk. However, some microorganisms that form spores, such as Bacillus cereus, B. licheniformis, B. pumillus, B. subtilis/amylolicuefaciens and $B$. megaterium can withstand heat applied during ultra-pasteurization (Pinto et al., 2018). There may also occur contamination after ultra-pasteurization due to deficiencies in the sealing of the containers. In this case, the contaminating microorganisms are not heat-resistant, as some aerobic mesophilic bacteria and can proliferate during milk storage (De Longhi et al., 2012). As there was no microbial presence detected in milk samples, it is safe to conclude that no post-sterilization contamination had occurred in the studied containers.

\section{Color changes}

The color is the first sensation a customer perceives of food, thus it is an essential attribute to accept and/or prefer a product. Food color awakens appetite, alerts of the hygienic condition of food, and gives a prediction of other sensorial food characteristics, such as taste and smell. The white color of milk is due to the casein micelles. The presence of lipids and small amounts of pigments such as carotenoids can give a yellow tone to the product (McDermott et al., 2016). Fig. 3A shows the changes in the whiteness index, WI, that occurred during ${ }^{\mathrm{LF}} \mathrm{LF}-\mathrm{UHT}$ and ${ }^{\mathrm{LF} S S}-\mathrm{UHT}$ milk storage. Whiteness indices at the beginning of storage fluctuated between 71 and 82

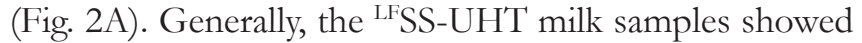
greater WI $(\mathrm{P}<0.05)$ than the ${ }^{\mathrm{LF}} \mathrm{LF}-\mathrm{UHT}$. An exception was brand A of the ${ }^{\mathrm{LF}} \mathrm{LF}-\mathrm{UHT}$ milk which WI was 80 . This behavior was similar ( $p>0.05$ ) to 90 days of storage. However, at the end of the useful life, a decrease $(p<0.05)$ of the WI of all the marks was observed, which coincided with the increase $(p>0.05)$ of the parameters $a^{*}$ and $b^{*}$ and therefore, resulted in a darkening of the milk (Fig. 3B and Fig. 3C).

Unusual color in freshly collected milk may be related to abnormalities such as mastitis. However, during storage, they are more likely to be due to chemical changes occurring in the system (McDermott et al., 2016). One of the consequences of subjecting milk to heat treatments such as ultra-pasteurization is the non-enzymatic darkening mediated by Maillard reactions. These reactions occur between the free $\varepsilon$-amino-groups of the milk proteins and the nonreducing carbohydrates present in the milk causing the formation of molecules that decrease the whiteness of the milk and that increase the yellow-brown coloration upon the storage (Jansson et al., 2014). The b* values, an average of all brands, changed from $3.43 \pm 0.03$ to $18.73 \pm 0.20$, from the beginning to the end of the storage. Larger $b^{*}$ values, being of yellow-blue tone determinant, are an indication of the development of Maillard reactions during storage. These reactions produce furfurales and polymerized compounds that introduce a brown color and rise to off-flavors often causing consumer rejection (Richards et al., 2016).

The $\mathrm{b}^{*}$ values found in this study were similar to those found by Sund et al. (2018) when storing skimmed UHT 


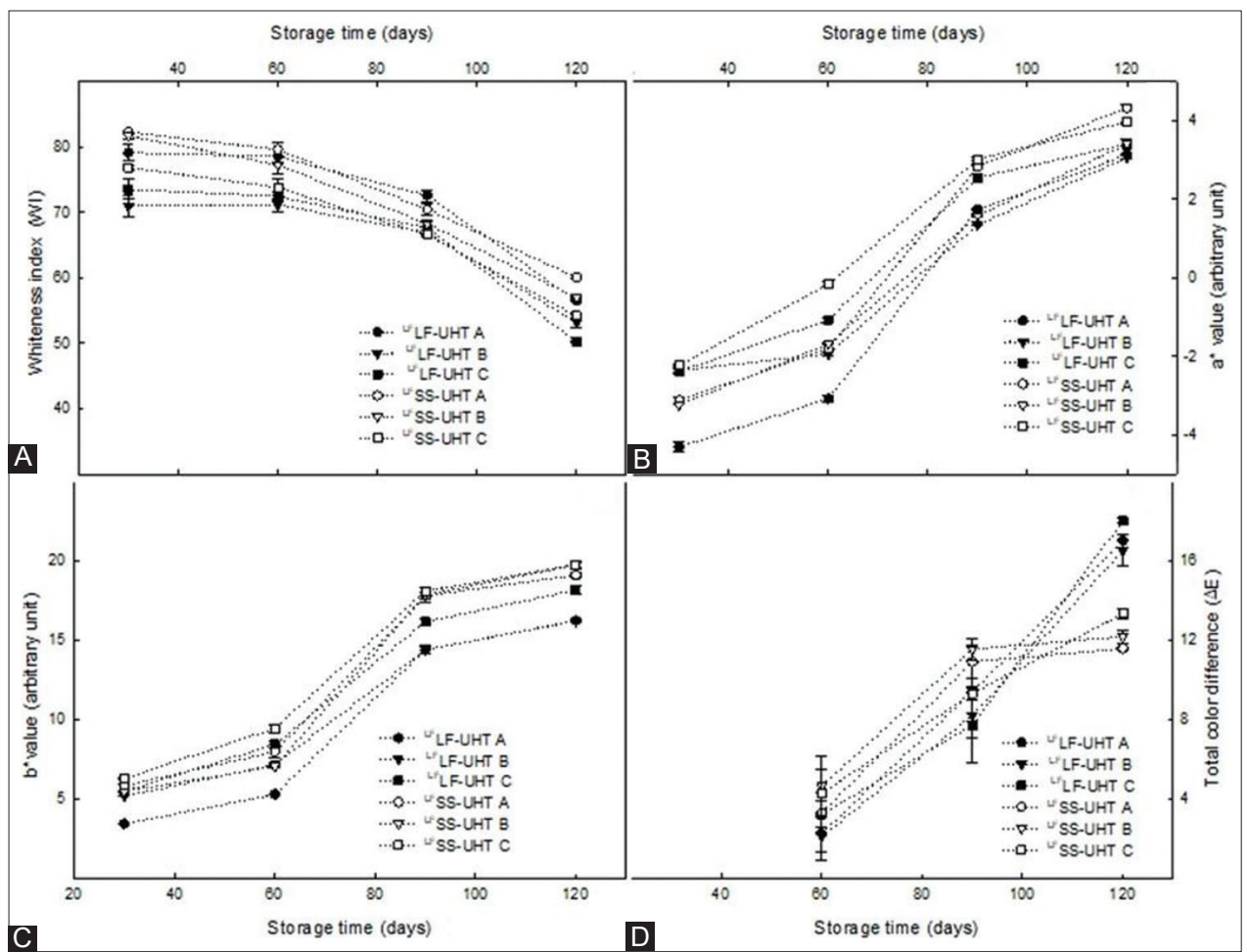

Fig 3. Color evolution of LFLF-UH and LFSS-UHT milk samples stored for 120 days. (A) whiteness; (B) $a^{*}$ value; (C) $b^{*}$ value; (D) Total color difference. The data are the means of triplicate experiments, and the error bars indicate error deviations.

milk at $40{ }^{\circ} \mathrm{C}$ for 25 weeks. However, lactose-free UHT milk, such as the ones in this study, are more susceptible to non-enzymatic darkening reactions than those containing lactose (Jansson et al. (2014). In industry, to eliminate lactose from milk, milk is treated with the lactase enzyme (3.2.1.23: $\beta$-D-galactosidase) which hydrolyzes lactose into glucose and galactose. This treatment doubles the amount of reducing sugars in milk allowing them to react with the free $\varepsilon$-amino groups of the lysine present in the proteins. Additionally, galactose and glucose can proceed through the Maillard reaction 20 to 10 times faster than lactose (Naranjo et al., 2013). Thus, a larger concentration of reducing sugars and ease in their reaction facilitates darkening in lactose-free milk after heat treatment.

The color difference $\left(\Delta \mathrm{E}^{*}\right)$ was determined by comparing the color of UHT milk at the beginning of shelf life (30 days of storage) and the other storing times. In accordance with Pagliarini et al. (1990), the values of $\Delta \mathrm{E}$ must be 3.8 or greater for the browning of milk to be visually appreciated. On the other hand, Sharma et al. (2005) established a value of 2.3 as JNP (just noticeable difference) to visually detect the color difference between two samples. All UHT milk samples showed values higher than $2.3(\mathrm{P}<0.05)$ after 60 days of storage (Fig. 2B). Color differences increased after 90 days of storage and became even more evident at 120 days of storage $(\Delta \mathrm{E}=11.5 \pm 0.07-18.0 \pm 0.14)$. Generally, the milk browning was higher $(\mathrm{p}<0.05)$ in ${ }^{\mathrm{LF}} \mathrm{LF}-\mathrm{UHT}$ milk

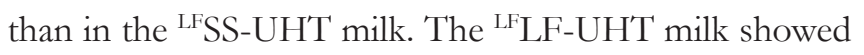
values between $16.5 \pm 0.76$ and $18.0 \pm 0.14$, while the LFSS-UHT milk between $11.5 \pm 0.07$ and $13.3 \pm 0.24$. This behavior is most likely due to differences in particle seizes discussed later. Likewise, the study by Dairy Innovation Australia Ltd showed changes of $\Delta \mathrm{E}$ of $20.3,13.4$, and 7.2, for lactose-free milk, semi-skimmed milk, and whole milk, respectively (stored at $35^{\circ} \mathrm{C}$ ) (Deeth and Lewis, 2017) confirming the fact that lactose-free milk shows highest browning degree.

\section{Size of the particles}

Changes in particle size were studied to examine the stability of casein micelles and their agglomeration behavior during ${ }^{\mathrm{LF}} \mathrm{LF}-\mathrm{UHT}$ and ${ }^{\mathrm{LF} S S}-\mathrm{UHT}$ milk storage. ${ }^{\mathrm{LF}} \mathrm{LF}-\mathrm{UHT}$ milk samples revealed a monomodal distribution with an average particle diameter between $186.3 \pm 4.0 \mathrm{~nm}$ and $224.9 \pm 6.1 \mathrm{~nm}$ during the first 90 days of storage (Table 2). The size of the casein micelles of the A and C milk brands (186.3 $\pm 4.9-192.3 \pm 5.4)$ were similar to the results obtained by Ciron et al. (2010), for homogenized non-fat milk $(183 \pm 2.3 \mathrm{~nm})$, while brand $\mathrm{B}$, showed larger sizes ( $p<0.05)$, possibly due to higher fat content (Deeth and Lewis 2017).

At 120 days of storage, the particle size distribution of ${ }^{\mathrm{LF}} \mathrm{LF}-\mathrm{UHT}$ became bimodal, exhibiting a large peak with average diameters between $145.3 \pm 2.4 \mathrm{~nm}$ and $158.5 \pm 6$. 
Table 2: Particle sizes of LFLF-UHT y LFSS-UHT milk

\begin{tabular}{|c|c|c|c|c|c|c|c|c|}
\hline \multirow[t]{3}{*}{ Brand } & \multicolumn{8}{|c|}{ LFLF-UHT } \\
\hline & \multicolumn{2}{|c|}{30 days } & \multicolumn{2}{|c|}{60 days } & \multicolumn{2}{|c|}{90 days } & \multicolumn{2}{|c|}{120 days } \\
\hline & Peak $1(\mathrm{~nm})$ & Peak 2 (nm) & Peak 1 (nm) & Peak 2 (nm) & Peak 1 (nm) & Peak 2 (nm) & Peak 1 (nm) & Peak 2 (nm) \\
\hline A & $188.5 \pm 3.4^{a}$ & -- & $192.3 \pm 5.4^{a}$ & -- & $187.0 \pm 2.3^{a}$ & -- & $145.3 \pm 2.4^{b}$ & $3317.67 \pm 175.7$ \\
\hline B & $210.3 \pm 7.2^{\mathrm{a}}$ & -- & $215.5 \pm 9.1^{a}$ & -- & $224.9 \pm 6.1^{a}$ & -- & $156.6 \pm 9.2^{b}$ & $2867.50 \pm 328.1$ \\
\hline \multirow[t]{2}{*}{ C } & $186.3 \pm 4.9^{a}$ & -- & $187.5 \pm 0.32^{\mathrm{a}}$ & -- & $188.8 \pm 5.9^{a}$ & -- & $158.5 \pm 6.7^{b}$ & $3817.7 \pm 175.7$ \\
\hline & \multicolumn{8}{|c|}{ LFSS-UHT } \\
\hline$A$ & $265.1 \pm 10.6^{a}$ & -- & $263.3 \pm 12.1^{a}$ & -- & $264.9 \pm 9.5^{a}$ & -- & $236.6 \pm 19.3^{b}$ & $3067.00 \pm 355.6$ \\
\hline B & $273.9 \pm 11.3^{a}$ & -- & $278.9 \pm 12.0^{\mathrm{a}}$ & -- & $245.4 \pm 11.1^{b}$ & $2600.2 \pm 284.4$ & $234.4 \pm 17.2^{\mathrm{b}}$ & $2946.17 \pm 112.1$ \\
\hline C & $264.3 \pm 9.7^{a}$ & -- & $264.2 \pm 11.2^{a}$ & -- & $245.5 \pm 18.0^{b}$ & $2596.3 \pm 396.2$ & $236.9 \pm 14.3^{b}$ & $3270.67 \pm 277.2$ \\
\hline
\end{tabular}

Values are means \pm error deviations. of three independent experiments. The different letters indicate statistically significant differences in the same brand $(p<0.05)$

$7 \mathrm{~nm}$ and a smaller peak with average diameters between $2867.5 \pm 328.1 \mathrm{~nm}$ and $3817.7 \pm 175.8 \mathrm{~nm}$. The peak with a larger average diameter represents casein aggregates and can be attributed in part to the destabilization of the casein in lower milk pH (Anema et al., 2019; Sinaga et al., 2017).

The decrease of $\mathrm{pH}$ produces the demineralization of the casein micelles thus destabilizing the surface layer formed by the $\mathrm{K}$ - casein (Sinaga et al., 2017). This, in turn, leads to the contraction of the casein micelles, resulting in a large population of particles with a smaller size of micelles, like the one in the first population of 120 day-stored milk. At the same time, the destabilization of casein increases the number of collisions between particles, causing the formation of less populated larger casein aggregates, such as those presented in the second population observed at 120 days of storage (Horne, 2014). A correlation between the decrease of $\mathrm{pH}$ and the destabilization of the micelles of casein has been observed before leading to a decrease in the whiteness of the milk. This change of color can be explained due to less light being reflected from smaller particles giving rise to a more translucent appearance of milk (Sinaga et al., 2017).

The LFSS-UHT milk from A brand showed a monomodal distribution of particle size during the first 90 days of storage and a bimodal after 120 days of storage. The other brands ( $\mathrm{B}$ and $\mathrm{C}$ ) showed a monomodal distribution during the first 60 days of storage and a bimodal after 90 days (Table 2). The peak of monomodal populations of all LFSS-UHT brands showed particle diameters size between $263.3 \pm 12.1 \mathrm{~nm}$ and $273.9 \pm 11.3 \mathrm{~nm}$. These particle sizes correspond to those previously reported for skim milk (McMahon et al., 2009). Bimodal distributions at day 120 in brand $A$ and day 90 in brand $B$ and $C$ were characterized by a larger peak with diameters size between $234.4 \pm$ $17.2 \mathrm{~nm}$ to $245.5 \pm 18.0 \mathrm{~nm}$ and a smaller, second peak with a micellar size greater than $2900 \mathrm{~nm}$. As mentioned in the case of ${ }^{\mathrm{LF}}$ LF-UHT milk the bimodal behavior could be due to the destabilization of casein micelles in correlation to the decrease in $\mathrm{pH}$ and whitening of milk.

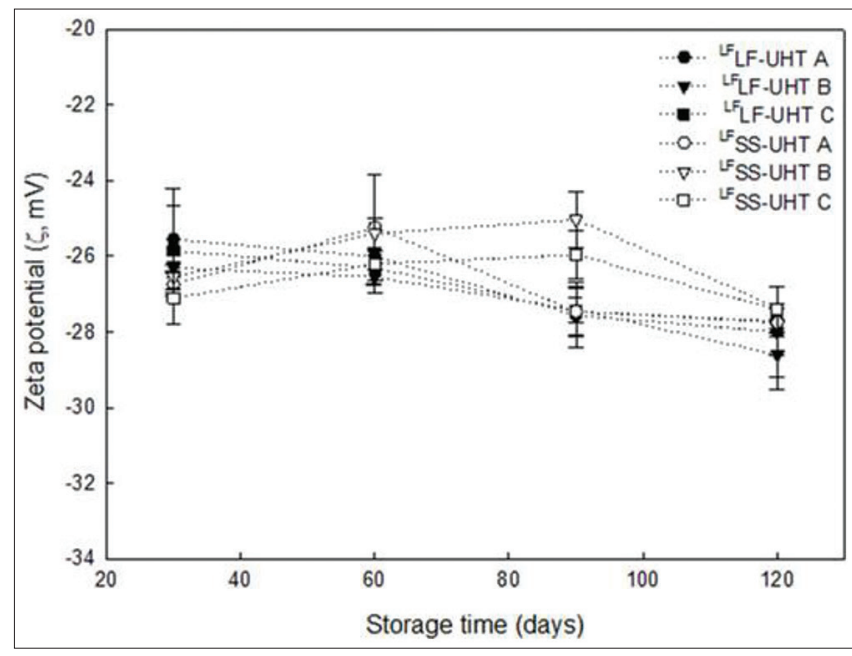

Fig 4. Zeta potential $(\mathrm{mV})$ of LFLF-UH and LFSS-UHT milk samples stored for 120 days. The data are the means of triplicate experiments, and the error bars indicate error deviations.

\section{Zeta potential}

Charge changes of particles during storage of ${ }^{\mathrm{LF}} \mathrm{LF}-\mathrm{UHT}$ and ${ }^{\mathrm{LF}} \mathrm{SS}-\mathrm{UHT}$ milk are shown in Fig. 4. The zeta potential values were retained in the range of $-25.5 \pm 1.3 \mathrm{mV}$ and $-28.6 \pm 0.9 \mathrm{mV}$. There was a slight decrease in the absolute values of zeta potential for the samples stored for the longest time (120 days), however, the differences were not significant $(p>0.05)$. The charges of the milk particles are mainly due to the charge carried by the casein micelles, although it can also be influenced by the fat globule membrane. Gaucher et al. (2008) reported values between -20 and $-17 \mathrm{mV}$ in skimmed UHT milk stored for 160 days at $40^{\circ} \mathrm{C}$. Some authors have shown that the charge of milk particles becomes more negative in the early stages of the Maillard reaction where lysine and arginine react with milk lactose (glucose-galactose) (Horne, 2014). On the other hand, the aggregation of the micelles in decreased $\mathrm{pH}$ can cause the particles to become less negative (Gaucher et al., 2008).

\section{Reaction with ortho-phthalaldehyde}

The reaction with ortho-phthalaldehyde was carried out to detect possible hydrolysis in the samples of ${ }^{\mathrm{LF}} \mathrm{LF}-\mathrm{UHT}$ and ${ }^{\mathrm{LF}} \mathrm{SS}-\mathrm{UHT}$ milk. The OPA reagent reacts with primary 


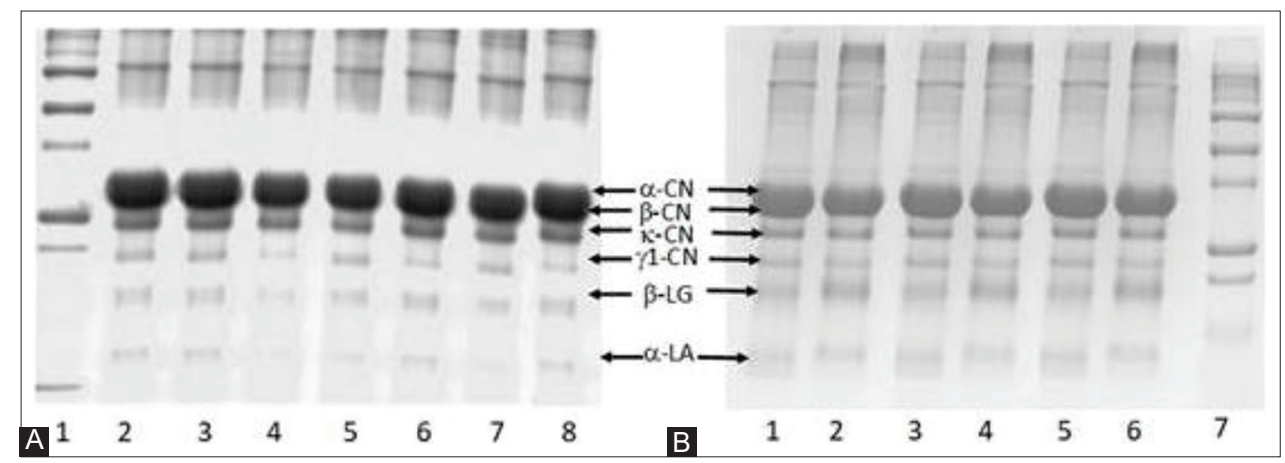

Fig 5. SDS-PAGE in $12 \%$ gel. (A) UHT milk samples stored for 30 days. Lane 1, molecular weight markers; lane 2, cero day control; lanes 3-5 LFLF-UHT milk brands A, B, and C respectively; lanes 6-8 ${ }^{\mathrm{LFSS}} \mathrm{S}-\mathrm{UHT}$ milk brands A, B, and C respectively. (B) UHT milk samples stored for 120 days. Lanes 1-3 LFLF-UHT milk brands A, B, and C respectively; lanes 4-6 LFSS-UHT milk brands A, B, and C respectively; lane 7 molecular weight markers.

amines of the hydrolyzed proteins giving rise to absorbance at $320 \mathrm{~nm}$ (Sunds et al., 2018). In this study, no significant changes in hydrolysis were detected $(\mathrm{p}>0.05)$, in any of the brands, during the 120 days of storage (data no show). The percentage of hydrolysis at the end of the storage was found between $6.1 \pm 0.3 \%$ and $7.9 \pm 2.0 \%$, while controls with non-enzymatic darkening showed percentages of hydrolysis between $29.6 \pm 3.8$ and $31.7 \pm 2.9 \%$. These results indicate that the degree of hydrolysis in all the milk brands was minimal.

\section{Electrophoretic characterization}

The electrophoretic pattern obtained for the three milk brands ${ }^{\mathrm{LF}} \mathrm{LF}-\mathrm{UHT}$ and ${ }^{\mathrm{LF}} \mathrm{SS}-\mathrm{UHT}$ at 30 days of storage, showed the proteins characteristic of milk ( $\alpha$ s1 casein, $\alpha$ s 2 casein, $\alpha$-lactalbumin, $\beta$-lactoglobulin) without detecting hydrolysis bands (Fig. 5A). Also, milk samples stored for 120 days showed no changes in protein composition (Fig. 5B). The lack of hydrolysis bands proves the absence of proteases in the stored milk.

Proteases that can hydrolyze milk and persist after the ultra-pasteurization process come from milk contamination with bacteria of the Pseudomona spp. and Serratia spp genera, particularly Pseudomona fluorescens and Serratia liquefaciens (Baglinière et al., 2017). The specificity of the proteases of these bacteria varies, however generally it attacks the $\mathrm{K}$ - casein in the link between Phe (105) and Met (106) of the 1-105 fragment forming insoluble peptide para- $\kappa$-casein with an apparent molecular mass of $16 \mathrm{kDa}$, localized between bands of $\beta$ - lactoglobulin and $\alpha$-lactalbumin. Additionally, it has been observed that the specificity of P. fuorescens for milk caseins follows the behavior $\beta$ - $>\alpha \mathrm{S} 1->\kappa_{-}>\alpha \mathrm{S} 2$ - casein (Baglinière et al., 2012). However, in this study, there is no evidence of bacterial contamination and the introduction of proteases into the milk. In addition, no changes in casein bands were observed for the ${ }^{\mathrm{LF}} \mathrm{LF}-\mathrm{UHT}$ and ${ }^{\mathrm{LF} S}$ UHT milk samples tested suggesting no change of casein structure upon initial heat treatment and no hydrolysis during storage. This is in accordance with literature that showed no changes in caseins subjected to different thermal processes (Baglinière et al., 2012).

\section{CONCLUSION}

The results from this study indicate that the useful shelf life of the three ${ }^{\mathrm{LF}} \mathrm{LF}-\mathrm{UHT}$ and ${ }^{\mathrm{LF}} \mathrm{SS}-\mathrm{UHT}$ milk brands should be limited to 90 days. Before 90 days of storage, the milk samples show stable micellar structure, color preservation, and sustaining of $\mathrm{pH}$ characteristics. At 120 days of storage, the $\mathrm{pH}$ decreased and the increase of titratable acidity was detected in all the samples. At the same storage time, significant browning of the milk was found indicating meaningful changes in the milk structure due to the progression of Millard's reactions, which possibly introduce off-flavors to milk (not studied here). The changes occurring in the lactose-free milk studied here are believed to be enhanced by the process of delactosylation of the milk, which introduces a large number of reducing sugars. These sugars, in turn, are easily reacting with $\varepsilon$-amino groups increasing the possibility of Millard reaction occurrence and resulting in darker products.

On the other hand, no microbial contamination was detected during the entire storage period, indicating a successful ultra-pasteurization process and a lack of posttreatment contamination.

\section{ACKNOWLEDGEMENTS}

The authors thank the National Council of Science and Technology (CONACyT) for the master student scholarship and the Institutional Analytical Platform (Plataforma Analítica Institucional) of the CIAD for the provided support. The authors thank Ana María Guzmán- 
Partida for training and technical support for the MC student.

\section{Author contributions}

Conceptualization, MCCW SGFM, and GRCM; Methodology, RAC and MCCW Validation, JEM, GRCM and SGFM; Formal Analysis, NMRG, RAC; Investigation, NMRG, MCCW and GRCM; Writing-Original Draft Preparation, NMRG, MCCW; Writing-Review \& Editing, JEM, GRCM; Supervision MCCW, RAC, and SGFM; Funding Acquisition MCCW and GRCM.

\section{REFERENCES}

Al-Saadi, J. M. S., A. M. Easa and H. C. Deeth. 2013. Effect of lactose on cross-linking of milk proteins during heat treatments. Int. J. Dairy Technol. 65: 1-6.

Al-Saadi, J. M. S. and H. C. Deeth. 2008. Cross-linking of proteins and other changes in UHT milk during storage at different temperatures. Aust. J. Dairy Technol. 63: 93-99.

Anema, S. G. 2019. Age gelation, sedimentation, and creaming in UHT milk: A review. Compr. Rev. Food. Sci. F. 18: 140-166.

Baglinière, F., J. Jardin, F. Gaucheron, A. F. de Carvalho and M. C. D. Vanetti. 2017. Proteolysis of casein micelles by heatstable protease secreted by Serratia liquefaciens leads to the destabilization of UHT milk during its storage. Int. Dairy J. 68: 38-45.

Baglinière, F., G. Tanguy, J. Jardin, A. Mateos, V. Briard, F. Rousseau, B. Robert, E. Beaucher, G. Humbert, A. Dary, J. L. Gaillard, C. Amiel and F. Gaucheron. 2012. Quantitative and qualitative variability of the caseinolytic potential of different strains of Pseudomonas fluorescens: Implications for the stability of casein micelles of UHT milks during their storage. Food Chem. 135: 2593-603.

Baldevbhai, P. J. and R. Anand. 2012. Color image segmentation for medical images using $L^{*} a^{*} b^{*}$ color space. IOSR J. Electron. Commun. Eng. 1: 24-45.

Bayless, T. M., E. Brown and D. M. Paige. 2017. Lactase nonpersistence and lactose intolerance. Curr. Gastroen. Rep. 19: 23.

Bradford, M. M. 1976. A rapid and sensitive method for the quantitation of microgram quantities of protein utilizing the principle of protein-dye binding. Anal. Biochem. 72: 248-254.

Briefel, R. R. and C. L. Johnson. 2004. Secular trends in dietary intake in the United States. Annu. Rev. Nutr. 24: 401-31.

Ciron, C. I. E., V. L. Gee, A. L. Kelly and M. A. E. Auty. 2010. Comparison of the effects of high-pressure microfluidization and conventional homogenization of milk on particle size, water retention and texture of non-fat and low-fat yoghurts. Int. Dairy J. 20: 314-320.

Datta, N. and H. C. Deeth. 2001. Age gelation of UHT milk a review. Food Bioprod. Process. 79: 197-210.

De Longhi, R., S. N, M. T. Nishimura, M. Y. Miyabe, L. C. Aragon-Alegro, M. De Rezende Costa and E. H. W. De Santana. 2012. A survey of the physicochemical and microbiological quality of ultra-heattreated whole milk in Brazil during their shelf life. Int. J. Dairy. Tech. 65: 45-50.

D'Incecco, P., V. Rosi, G. Cabassi, J. A. Hogenboom and L. Pellegrino. 2018. Microfiltration and ultra-high-pressure homogenization for extending the shelf-storage stability of UHT milk. Food Res. Int. 107: 477-485.
Deeth, H. C. and M. J. Lewis. 2017. High Temperature Processing of Milk and Milk Products. Wiley Blackwell, Chichester, UK.

Dekker, P. J. T., D. Koenders and M. J. Bruins. 2019. Lactose-free dairy products: Market developments, production, nutrition and health benefits. Nutrients. 11: 551.

Faist, V., S. Drusch, C. Kiesner, I. Elmadfa and H. F. Erbersdobler. 2000. Determination of lysinoalanine in foods containing milk protein by high performance chromatography after derivatisation with dansyl chloride. Int. Dairy J. 10: 339-346.

FDA. 1998. Bacteriological Analytical Manual. AOAC, International, Gaithersburg, MD.

FDA. 2008. Skimming the Milk Label. Food and Drug Administration, Silver Spring, Maryland. Avaialble from: http://www.fda.gov/fdac/ features/1998/198_milk.html. [Last accessed on 2020 Mar 24].

Gaucher, I., D. Mollé, V. Gagnaire and F. Gaucheron. 2008. Effects of storage temperature on physicochemical characteristics of semi-skimmed UHT milk. Food Hydrocoll. 22: 30-143.

Gaur, V., J. Schalk and S. G. Anema. 2018. Sedimentation in UHT milk. Int. Dairy J. 78: 92-102.

Hawran, L. J., V. A. Jones and K. R. Swartzel. 1985. Sediment formation in aseptically processed and packaged milk. J. Food Proc. Preserv. 9: 189-207.

Holland, J. H., R. Gupta, H. C. Deeth and P. F. Alewood. 2011. Proteomic analysis of temperature-dependent changes in stored UHT milk. J. Agric. Food Chem. 59: 1837-1846.

Horne, D. S. 2014. Milk Proteins. Academic Press, San Diego, CA

Horwitz, W. 2000. Official Methods of Analysis of AOAC International. AOAC International, Gaithersburg, MD.

Jansson, T., H. B. Jensen, U. K. Sundekilde, M. R. Clausen, N. Eggers, L. B. Larsen, C. Ray, H. J. Andersen and H. C. Bertram. 2014 Chemical and proteolysis-derived changes during long-term storage of lactose-hydrolyzed ultrahigh-temperature (UHT) milk. J. Agric. Food Chem. 62: 11270-11278.

Laemmli, U. K. 1970. Cleavage of structural proteins during the assembly of the head of bacteriophage T4. Nature. 227: 680-685.

Lewis, M., A. Grandison, M. Lin and A. Tsioulpas. 2011. Ionic calcium and $\mathrm{pH}$ as predictors of stability of milk to UHT processing. Milchwissenschaft. 66: 197-200.

Lu, J., M. Langton, S. Sampels and J. Pickova. 2019. Lipolysis and oxidation in ultra-high temperature milk depend on sampling month, storage duration, and temperature. J. Food Sci. 84: 1045-1053.

Malmgren, B., Y. Ardö, M. Langton, A. Altskär, M. G. E. Bremer, P. Dejmek and M. Paulsson. 2017. Changes in proteins, physical stability and structure in directly heated UHT milk during storage at different temperatures. Int. Dairy J. 71: 60-75.

McDermott, A., G. Visentin, S. McParland, D. P. Berry, M. A. Fenelon and M. De Marchi. 2016. Effectiveness of mid-infrared spectroscopy to predict the color of bovine milk and the relationship between milk color and traditional milk quality traits. J. Dairy Sci. 99: 3267-3273.

McMahon, D. J., H. Du, W. R. McManus and K. M. Larsen. 2009. Microstructural changes in casein supramolecules during acidification of skim milk. J. Dairy Sci. 92: 5854-5867.

Molina, L. H., R. González, C. Brito, B. Carrillo and M. Pinto. 2001 Correlación entre la termoestabilidad y prueba de alcohol de la leche a nivel de un centro de acopio lechero. Arch. Med. Vet. 33: $233-240$

Naranjo, G. B., A. S. Pereyra Gonzales, G. E. Leiva and L. S. Malec. 2013. The kinetics of Maillard reaction in lactose-hydrolyzed milk powder and related systems containing carbohydrate mixtures. 
Food Chem. 141: 3790-3795.

NOM-155-SCFI-SCFI-2012. 2012. Leche Denominaciones, Especificaciones Fisicoquímicas, Información Comercial y Métodos de Prueba. Avaialble from: http://www.dof.gob.mx/ normasOficiales/4692/seeco/seeco.htm. [Last accessed on 2020 Apr 02].

Pagliarini, E., M. Vernile and C. Peri. 1990. Kinetic study on color changes in milk due to heat. J. Food Sci. 55: 1766-1767.

Pinto, C. L. O., L. V. Souza, V. A. S. Meloni, C. S. Batista, R. Silva, E. M. F. Martins, A. G. Cruz and M. L. Martins. 2018. Microbiological quality of Brazilian UHT milk: Identification and spoilage potential of spore-forming bacteria. Int. J. Dairy Tech. 71: 20-26.

Richards, M., E. M. Buys and H. L. De Kock. 2016. Survival analysis, consumer perception and physicochemical analysis of low fat UHT milk stored for different time periods. Int. Dairy J. 57: 56-61.

Sharma, G., W. Wu and E. N. Dalal. 2005. The CIEDE2000 colordifference formula: Implementation notes, supplementary test data, and mathematical observations Color Res. Appl. 30: 21-30.

Silanikove, N., G. Leitner and U. Merin. 2015. The interrelationships between lactose intolerance and the modern dairy industry: Global perspectives in evolutional and historical backgrounds. Nutrients. 7: 7312-7331.

Silvestre, M. P. C., M. R. Silva, V. D. M. Silva, M. W. S. Souza, C. D. O. Junior and W. D. O. Afonso. 2012. Analysis of whey protein hydrolysates: Peptide profile and ACE inhibitory activity. Braz. J Pharm. Sci. 48: 747-757.

Sinaga, H., N. Bansal and B. Bhandari. 2017. Effects of milk pH alteration on casein micelle size and gelation properties of milk. Int. J. Food Prop. 20: 179-197.

Singh, H. and J. M. Latham, J. M. 1993. Heat stability of milk: Aggregation and dissociation of protein at ultra-high temperatures. Int. Dairy J. 3: 225-237.

Stoeckel, M., M. Lidolt, V. Achberger, C. Glück, M. Krewinkel, T. Stressler, M. von Neubeck, M. Wenning, S. Scherer, L. Fischer and J. Hinrichs. 2016. Growth of Pseudomonas weihenstephanensis, Pseudomonas proteolytica and Pseudomonas sp. in raw milk: Impact of residual heat-stable enzyme activity on stability of UHT milk during shelf-life. Int. Dairy J. 59: 20-28.

Sunds, A. V., V. M. Rauh, J. Sørensen and L. B. Larsen. 2018. Maillard reaction progress in UHT milk during storage at different temperature levels and cycles. Int. Dairy J. 77: 56-64.

USDA. 2018. Mexico. Dairy and Products Semi-annual. Available from: https://www.gain.fas.usda.gov/Recent $\% 20$ GAIN\%20 Publications/Dairy\%20and\%20Products\%20Semi-annual_ Mexico\%20City_Mexico_5-18-2018.pdf. [Last accessed on 2020 Mar 24].

Ye, R. and F. Harte. 2013. Casein maps: Effect of ethanol, pH, temperature, and $\mathrm{CaCl}_{2}$ on the particle size of reconstituted casein micelles. J. Dairy Sci. 96: 799-805. 